\title{
Knowledge Enhancement of Field School Participants and Perception on Shallot Multiple Production Program (Proliga) in Sigi District
}

\author{
Heni SP Rahayu ${ }^{1, *}$, Risna $^{1}$, and Saidah ${ }^{1}$ \\ ${ }^{1}$ Central Sulawesi Assessment Institute of Agricultural Technology, Indonesia
}

\begin{abstract}
Shallot's fluctuations in production are able to influence the inflation rates where a deficit on shallot supply makes the price of shallot in the high level. One program to increase shallot's production is through Multiple Production Programs or Proliga which mainly use True Seed of Shallot. To spread these technologies, a dissemination method is needed, one is through the field school (FS) for extension workers and potential shallot farmers. An evaluation needs to be carried out to assess the effectiveness of the dissemination. The study aims to determine the increase in participant's knowledge after attending the field school of shallot and their perception to the technologies. Data collection used a questionnaire taken twice, namely the initial test (pre-test) and the final test (post-test) after the field school activities. Data were analyzed using non-parametric Wilcoxon Match Pairs Test statistics. Farmer perceptions were analyzed using scoring method. The results of the analysis showed that the proliga field school activities significantly increased participants' knowledge with significance at $5 \%$ confidence level and the percentage of participants who increased their knowledge as much as $95.65 \%$. Generally, farmers were interesting on the technology in Proliga but need a technology improvement on TSS to get easier application.
\end{abstract}

\section{Introduction}

Shallot is one of the main national vegetable commodities that farmers have been working intensively for a long time. Apart from being the main spice for household-level, shallots also have potential to be used as industrial raw materials such as the fried shallot industry or other food industries and also as biopharmaceutical sources for its flavonoids, quercetin and quercetin glycosides. Those mainly can be used for prevention and treatment of various diseases such as diabetes, cancer, coronary heart disease, etc. [1]. The high population growth leads the high need of food ingredient such as shallot. The need for shallot in the future must be accompanied by increased production. The productivity of shallots in Central Sulawesi in 2018 was 5.04 ton/hectare [2] which still under the national production.

In general, shallots are cultivated using seed tubers. The problem is the high cost of seed tubers, which is more $40 \%$ of the total production costs [3]. In addition, the quality of seed

\footnotetext{
* Corresponding author: sulistyawati79@gmail.com
} 
tubers is not guaranteed because it is often carried by disease pathogens, such as Fusarium $s p$., Colletothricum sp., Alternaria sp., and viruses from the original plants that are attacked, so that it can reduce productivity. True Seed of Shallot (TSS) is one of alternatives solution for these problems. The use of TSS has several advantages compared to seed tubers. It has volume's need only 3-4 kg/ha, compare to seed tubers 1-1.5 t/ha. Transportation and storage also easier and cheaper in TSS. Other main advantage is producing healthier plants because TSS is free of disease pathogens and produces higher quality, larger tubers. Furthermore, [4] reports that the use of TSS is more economically feasible because it can increase yields by two times compared to using seed bulbs. For this reason, Balitbangtan has introduced double production program (Proliga) as a program to increase productivity which mainly use TSS as plant material.

Proliga (Multiple Production Program) is a technological package in increasing the production of shallots from around 10 tons/ha to more than $30 \mathrm{t} / \mathrm{ha}$. The proliga technology package includes: 1) Application of True Seed of Shallot (TSS) technology, 2) Increasing plant population, 3) Management of nutrients and water supply, 4) Suppressing yield losses by managing pests and diseases preventively and anticipatively which friendly to the environment.. Horticultural commodities are high value commodities with high risk. With high capital costs, the risk of farmers experiencing large losses is also high. One effect of this condition is the high use of pesticides on horticultural commodities, especially shallot. Thus, a need of technological approaches which increasing high production while being environmentally friendly. This new technology approach requires the right dissemination method to reach its users, namely extension workers and farmers.

Technology innovation dissemination has compound processes in the field based on the way farmers's learn and the structure of extension interventions happen [5]. The productive system needs to focus on the qualify environment for representative to be stimulated to work as directed [6]. Agricultural extension has a huge prospective to increase agricultural productivity and improve revenue through delivering and assistance of knowledge, skills, and technologies [7,8]. Field school is one of the dissemination media that is currently widely used. According to [9] the field school is a periodic meeting activity carried out by a group of people at a certain level, beginning with discussing the problem being faced, then followed by brainstorming, various experiences (sharing), effective and efficiency in accordance with the resources. Moreover, [10] stated that teaching with more practices in agriculture helped student to understand more. However, an evaluation of the Field School needs to be carried out to find out the increase in knowledge after attending FFS as well as to assess the effectiveness and farmer perception to the program. agricultural experiences. [9] suggested that through evaluations, conclusions can be drawn about everything that happened, as well as providing a foundation and direction for further activities which need to be done. This study aims to determine changes or increase in knowledge and their perception of the technologies after participating in the farmer school.

\section{Methodology}

The assessment was carried out in May until September 2019 in Kotarindau Village, Dolo Sub-district, and Sigi Regency. Data collection using questionnaires filled out by respondents. Respondents interviewed were 23 people who were all field school participants. The data collected consists of the characteristics and data of the initial test (pretest) which was conducted before the material is given and the final test (post-test) which was carried out after the activity. Data were analyzed using non-parametric Wilcoxon Match Pairs Test statistics with the following hypotheses: "There is a significant difference in the knowledge of participants before and after attending the Proliga Field School". After 
attending Proliga FS, participants' knowledge about Proliga technology packages is better or higher compared to before.

Test criteria:

Ho: there is no difference in knowledge before and after Proliga FS

H1: there is a difference in knowledge before and after Proliga FS

Farmer perception was analyzed using scoring method [11] as follows:

$\mathrm{ni}=$ Number of respondent at column $\mathrm{i}(\mathrm{i}=1,2,3, . .4)$

$$
\text { Score Value }=\frac{n i . s i}{N}
$$

$\mathrm{si}=$ Score of comment in $\mathrm{i}(\mathrm{i}=1,2,3, \ldots 4)$

$\mathrm{N}=$ Total number of the respondent (23)

Perception was measured using a Likert scale which is divided into four scales.

The scale is the general confirmed psychometric tool that admits for a quantitative assessment of beliefs about extension and innovation [12].

\section{Result and Discussion}

\subsection{Characteristics of Respondents}

Characteristics of respondents are needed to know the process of perception of innovation that is highly dependent on internal factors of the adopter itself [13]. Characteristics of respondents in the Field School (FS) of proliga are presented in Table 1.

Table 1. Characteristics of respondents Field School (FS) in Shallots in Sigi Regency, 2019

\begin{tabular}{|c|c|c|c|c|}
\hline No & Characteristic of respondents & Group & Number & Percentage (\%) \\
\hline 1 & Age & $\begin{array}{l}25-40 \text { year } \\
41-55 \text { year } \\
56-65 \text { year }\end{array}$ & $\begin{array}{c}9 \\
10 \\
4\end{array}$ & $\begin{array}{r}39.13 \\
43.48 \\
17.39\end{array}$ \\
\hline \multicolumn{3}{|c|}{ Sum } & 23 & 100 \\
\hline 2 & Education & $\begin{array}{l}\text { Elementary } \\
\text { Junior High School } \\
\text { Senior High School } \\
\text { Undergraduate } \\
\text { Post graduate }\end{array}$ & $\begin{array}{c}4 \\
2 \\
11 \\
4 \\
2\end{array}$ & $\begin{array}{r}17.39 \\
8.70 \\
47.83 \\
17.39 \\
8.70\end{array}$ \\
\hline \multicolumn{3}{|c|}{ Sum } & 23 & 100 \\
\hline 3 & Farming Experienced & $\begin{array}{l}\text { 5-10 Years } \\
11-20 \text { Years } \\
21-30 \text { Years } \\
31-40 \text { Years }\end{array}$ & $\begin{array}{c}13 \\
7 \\
1 \\
2\end{array}$ & $\begin{array}{r}56.52 \\
30.43 \\
4.35 \\
8.70\end{array}$ \\
\hline \multicolumn{3}{|c|}{ Sum } & 23 & 100 \\
\hline
\end{tabular}

Table 1 shows that generally participants are in productive age so that they still have a high level of enthusiasm to receive new technological innovations delivered. [14] suggested that the age of farmers is one indicator of farm success. A person of productive age in general has a fairly high willingness to develop knowledge and skills in accepting new innovations [15]. Farmers of productive age tend to have the spirit to want to know things that are not yet known so that farmers will try to more quickly adopt innovations even though they actually have no experience in implementing these technological innovations. Age affects the attitude of learning, understanding and adopting innovation in a business, increasing productivity and physical ability to work as well as ways of thinking. Furthermore [16] stated that younger 
farmers in terms of age and farming experience, have a greater likelihood of accepting ideas, and can slightly abandon the old methods.

Education is one of determining factor in whether so that the material that was delivered can be easily understood and can accelerate the adoption technological innovations by extension officer. Participant of Field School can be categorized as educated enough because of its education level. The higher the level of education of a person related to the higher of absorbtion capacity technology and faster to receive innovation. Farming experience ranges from five to forty years which suggest that respondents have been important for the success of the capital of the farming. Experience in farming also influence the way of managing the farms. More experienced mean more knowledge get in managing farm. Furthermore [15] stated that farm-demonstrations were found to be involving later generation of farmers who are in stage of being able to implement long-term innovations.

\subsection{Field School Material}

Diseminating technology should consider selecting farmer trainers, organizing training, types of technologies to disseminate [17]. Field school material is based on the technical guidelines for cultivation on multiple shallots production (proliga) which is presented in Table 2.

Table 2. Materials of proliga field school in Sigi District, 2019

\begin{tabular}{|c|l|}
\hline No & \multicolumn{1}{c|}{ Field School Material } \\
\hline 1 & Field preparation using organic material \\
\hline 2 & Planting of True Seed of Shallot (TSS) \\
\hline 3 & Recommendation of Fertilization \\
\hline 4 & Controlling Plant and diseases using Integrated Pest Management \\
\hline
\end{tabular}

The material presented in field school related to recommendations or technical instructions for the implementation of the shallot proliga. First material is field preparation which use organic material as fertilizer around 2 ton per hectare. Organic fertilizer is very important to improve the soil quality by escalating the soil's ability to hold water and nutrients and decreases the erosion and soil crusting caused by rain and wind. Other benefits of using organic fertilizer are: ads more natural nutrients, feed important microbes in the soil and improves the structure of the soil.

Second materials is planting of TSS to multiple the populations and solve seed's problems such as very expensive bulb, reaching IDR 50,000 per kilo with the need to reach 1 ton of tubers per hectare. [9] stated that farmers expected to get recommendations that must be implemented, by farmers often highly expected by farmers, and material containing problem solving is the main requirement needed. [18] stated that material of dissemination must be a new technology which has function as problem solving for the target. Furthermore, the material has to be suitable for the farmer's needs. Third material is recommendation of fertilization which based on result of Soil Test Kit. The benefit of using Soil Kit Test is fertilizer will be given in the right amount or dosage. The dissemination technologies also include correct kind, way, and time of fertilizer application.

One of the problems in shallot production is plant pest attack and diseases thus plant and diseases management is an important topic. The high risk of shallot in economic as a reason for farmer to overuse of pesticides. Therefore, a required of technological approach which controlling plant and diseases but keep considering on environment such as Integrated Pest Management. The use of biological agent is alternative solution to diminish the danger of excessive pesticide as dangerous and not degradable chemical which pollute the environment. 


\subsection{Knowledge Enhancement}

Knowledge is an intellectual ability and memory in applying concepts to problem solving in the field $[19,20]$. Knowledge can be increased using a number of methods both formally and informally. One of them is through the field school of cultivation technology of Proliga which consist of lecture, discussions and demonstration methods. Increased knowledge of participants is calculated based on pre-test and post-test scores. The calculation results show an average pre-test result of 60.00 and an average post-test of 70.00 , so it can be said that the field school increases the knowledge of participants. According to [9] the field school is a periodic meeting activity carried out by a group of people at a certain level, beginning with discussing the problem being faced, then followed by brainstorming, various experiences (sharing), effective and efficiency in accordance with the resources owned.

The most impotant variable for Farmer Field School to get adoption is increasing knowledge as part of decision making process [21]. Based on the distribution of the scores shown in Figure 1, it can be seen that there was a dynamic or an increase in knowledge after the field school was implemented. In general, participants' knowledge, namely farmers and extension workers, increased. Submission of technology that is equipped by practices or demonstrations are easier to be understood by farmer.

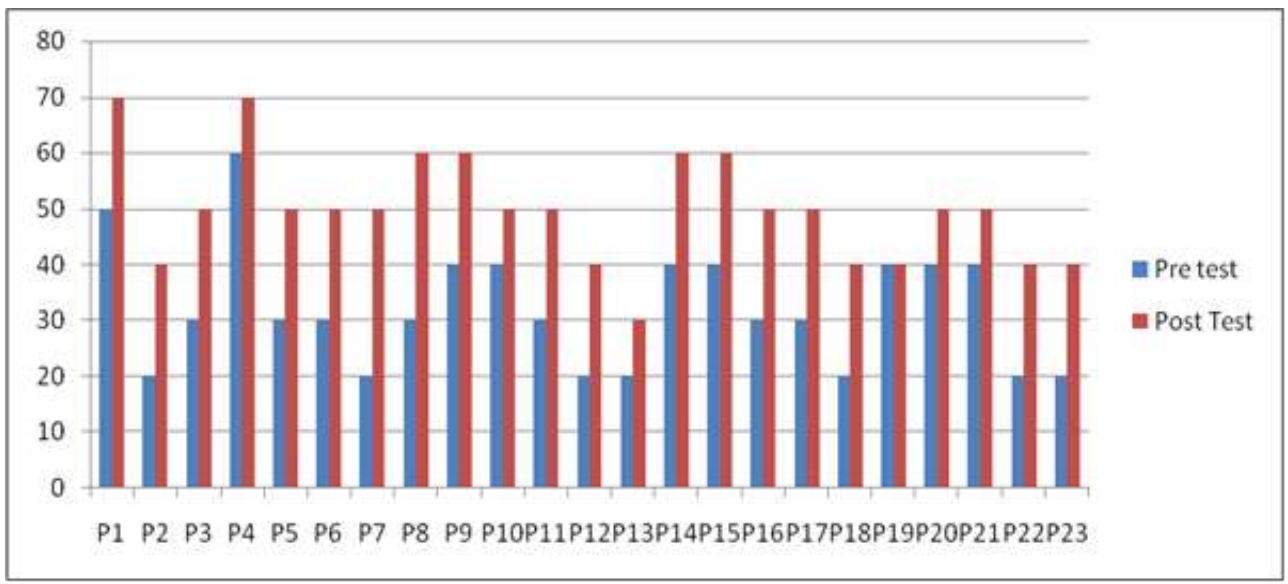

Fig. 1. Development of participant's knowledge based on pretest and post test scores Proliga Field School in Sigi Regency, 2019

The adapted Farm Field School could be appraised as a positive approach to training farmers, simultaneously identifying and discovering adaptations of agricultural innovations. [22]. Furthermore, [23] stated that participation in FFSs led to increased production, productivity, and revenue in nearly all cases.

\subsection{Summary of changes in respondent's knowledge}

Descriptive statistics in Table 3 shows that the lowest pre-test value is 20 and the highest value is 60 with a mean of 32.17, while the lowest post-test value is 30 and the highest is 70 . The mean or post-test score of 50 is greater than the pre-test value is 49.72 . Furthermore, in order to determine the differences or changes in knowledge gained, the Wilcoxon Signed Rank Test is performed. Changes in knowledge after the field school are shown in Table 3. 
Table 3. The changes of knowledge's participants of Proliga Field School in Sigi District, 2019.

\begin{tabular}{|l|c|c|c|c|c|}
\hline Items & Number (N) & $\begin{array}{c}\text { Minimum } \\
\text { Value }\end{array}$ & $\begin{array}{c}\text { Maximum } \\
\text { Value }\end{array}$ & Mean & $\begin{array}{c}\text { Deviation } \\
\text { standard }\end{array}$ \\
\hline Pretest & 23 & 20 & 60 & 32.17 & 10.85 \\
\hline Posttest & 23 & 30 & 70 & 50.00 & 10.00 \\
\hline Number (N) & 23 & & & & \\
\hline
\end{tabular}

Changes in knowledge of participants based on pre-test and post-test as a result of the implementation of the field school are (a). No participants gained negative rank or experienced a decrease in knowledge, (b). Participants who experienced an increase in knowledge (positive ranks) of 22 people with mean ranks of 11.50 and sum of ranks or the total ranking of 253.00. (c). As many as one person did not experience an increase in knowledge (ties). From the data it is known that an increase in knowledge of $95.65 \%$. The results of statistical tests on changes in knowledge are shown in Table 4.

Table 4. Ranks of field school participant in Sigi District, 2019.

\begin{tabular}{|l|l|c|c|c|}
\hline Term & N & Mean Rank & Sum of rank \\
\hline Posttest- pretest & $\begin{array}{l}\text { Negative } \\
\text { Ranks }\end{array}$ & 0a & 00.00 & 00.00 \\
\hline & $\begin{array}{l}\text { Positive } \\
\text { Ranks }\end{array}$ & $22 \mathrm{~b}$ & 11.50 & 253.00 \\
\hline & Ties & $1 \mathrm{c}$ & & \\
\hline & Total & 23 & & \\
\hline
\end{tabular}

Noted: a. Posttest $<$ pre test

b. Posttest $>$ pre test

c. Posttest $=$ pre test

Changes in knowledge can occur if the material presented is in accordance with the characteristics and needs of the participants, as well as the methods used in implementing field schools. Extension materials are messages that the instructor communicates to the target community (farmers). The message must be innovative that is able to change or encourage change, so that improvements in the quality of life of every individual and the whole community are realized. Material delivered will be accepted so as to increase farmers' knowledge, if the material can provide relative benefits for farmers. [24] stated that the relative advantage becomes a priority assessment in decision making adoption of technological innovation. The method used is a combination of field schools, lectures, discussions and demonstrations. The results of [25] research, the counseling methods (field schools, and demonstration plots) are in accordance with the preferences of respondents to accelerate communication through "face-to-face meetings". The results of research conducted $[26,27]$ that the results of pre-test and post-test after counseling with lecture and discussion methods have increased knowledge.

Statistically there were significant differences in knowledge before and after the implementation of the Field School shown in Table 5.

Table 5. Summary of Wilcoxon Signed Rank Test, field school participant Proliga Sigi district, 2019

\begin{tabular}{|c|c|c|c|}
\hline Null hypothesis & Significance level & $\begin{array}{c}\text { Wilcoxon } \\
\text { significance }\end{array}$ & Decision \\
\hline $\begin{array}{l}\text { No difference knowledge } \\
\text { level of Field School participant }\end{array}$ & 0.05 & 0.000 & Ho is rejected \\
\hline
\end{tabular}

Based on the results of the Wilcoxon Signed Rank Test calculation, the $Z$ value obtained was -4.274 with a p value (Asymp. Sig 2 tailed) was 0,000 which is less than the critical limit of research 0.05 . This shows that H1 was accepted or the knowledge of field school's 
participants' shallot technology before and after Proliga differed significantly or had a significant effect in increasing the knowledge of field school participants.

\subsection{Farmer perception on Proliga}

Farmers' perception on Proliga was assessed based on the reasons statement by farmers. Perception was measured using a Likert scale which is divided into four scales. The decision of farmers to apply technology is mainly determined by internal factors within the farmer, including the attitude and purpose in conducting farming. Generally, the goal of farmers in carrying out their farming business is to increase the family income by increasing production. Proliga as one of the alternative ways to increase shallot's production and farmer'sincome. However, farmer perception will be influenced in many factors. The low level of technology adoption by farmers is influenced by many factors, including the lack of capital, high input prices, and low output prices.

Table 6. Summary of Farmer perception on Proliga in Sigi District, 2019

\begin{tabular}{|c|l|c|}
\hline No & \multicolumn{1}{|c|}{ Materi } & Skor \\
\hline 1 & Field preparation using organic material & 3.12 \\
\hline 2 & Planting of True Seed of Shallot (TSS) & 2.56 \\
\hline 3 & Recommendation of fertilization & 3.51 \\
\hline 4 & Controlling plant and diseases using Integrated Pest Management & 3.10 \\
\hline
\end{tabular}

Table 6 shows that generally all participant especially farmer interest to Proliga package of technology. Organic materials are available in the location. Farmer can buy organic fertilizer in affordable price. Before the field school some farmers already use organic fertilizer, but not in correct amount. Recommendation fertilization using Soil Test Kit become a guidance for farmer in location to put correct kind, amount, and time of application. Farmer believe that to get optimum production, they need to give enough fertilizer to the plant while overused of fertilizer will make shallot juicer so that easy to get rotten. The application of integrated pest management such as refugia plant, feromon exi were useful for controlling pest, however farmer still want to use pesticide whether plant pest and diseases above of economic threshold.

TSS is a new technology for mostly participant. The economic aspect had as reason for farmer interest to TSS. The statement of the farmer that the benefits of using TSS are commensurate with the cost of changing technology had the highest value. Based on what was seen in demonstrations that have been implemented, the farmers assessed that the costs incurred to change the technology to the TSS are commensurate with the benefits earned so that it is worth trying. However, the technical application of TSS is still difficult for farmer especially in seedling and planting. Therefore, there is a need to improve this technology in order to get easier application. Model of Proliga FFS similar to an education programme in Canada which contributes to an agroecological in promoting agricultural knowledge such as teaching the agroecology practice through both experiential and theoretical training; and, building a supportive community [28].

\section{Conclusion and Recommendation}

Proliga is one alternative shallot production acceleration which in friendly environment program. As dissemination media, proliga field school has a very significant effect on participants' knowledge at 5\% significance. The knowledge's enhancement of Proliga after field school increased by $95.65 \%$. All participant especially farmers were interesting on packet of technology especially material organic for soil conservation, integrated pest 
management, fertilization recommendation while still need a technology improvement on TSS to get easier application. Hence TSS is still a new technology in Central Sulawesi, knowledge improvement, farmer perception, and level of technology adoption should be continued by research on adoption of Proliga technology as evaluation to what extent the technology has been applied by farmers.

Acknowledgement. Acknowledgment goes to Dr. Ir. Fery Fahruddin Munier, M.Sc as the Head of Central Sulawesi Assessment Institute for Agricultural Technology (AIAT) for supporting the study

\section{References}

1. F. Merhi, J. Auger, F. Rendu, and B. Bauvois. Allium compounds, dipropyl and dimethyl thiosulfinates as antiproliferative and differentiating agents of human acute myeloid leukemia cell lines. Abstract Biologics. Dec 2(4): 885-95. (2008).

2. Statistic Center Agency. Harvest area, Production, and Yield of Horticulture Central Sulawesi 2016. http://www.sulteng.bps.go.id. (2018).

3. HSP .Rahayu., Yorobe, JM., Quicoy, CB. Profitability of Local Shallot Farms under Different Watering Systems in Central Sulawesi Indonesia. International Journal of Agriculture Innovations and Research. 7 (1). (2018).

4. R.S. Basuki. Technical and Economic feasiblity on True Seed of Shallot and Traditional Seed on Shallot. Horticulture Journal. 19 (3): 5-8. (2009).

5. K ,Davis,. E ,Nkonya,. E,Kato., DA, Mekonmen., M ,Odendo., R,Miiro., J,Nkuba.. Impact of Farmer Field Schools on Agricultural Productivity and Poverty in East Africa. Discussion Paper. International Food Policy Research Institute. (2010).

6. C, Ragasa., J, Ulimwengu., Randriamamonjay., T,Badibagan. Agricultural Extension: Evidence from Democratic Republik of Congo. The Journal of Agrcultural Education and Extension. DOI:10.1080/1389224X.2015.1026363. (2015).

7. F.G.J, Anderson., R, Birner., K ,Deininger. Promises and Realies of Community based Agricultural Extension. Discussion Paper. International Food Policy Research Institute. (2010).

8. B, Swanson., and R, Rajalahti. Strengthening Agricultural Extension and Advisory Systems: Procedures for Assessing, Transforming, and Evaluating Extension Systems. ARD Discussion Paper 20. Washington, DC: World Bank. (2010)

9. T. Mardikanto, P. Soebianto. Community empowerment in the perspective of public policy. Bandung (Indonesia): Alfabeta. (2015).

10. SJ, Jeong and SJ, Choi. Agricultural literacy in the context of agricultural education in South Korea: using hierarchical linear modeling, The Journal of Agricultural Education and Extension. DOI: 10.1080/1389224X.2020.1748670. 20 p. (2020).

11. R, Hendayana,. Perception and Adoption. IAARD Press. Jakarta 67 p. (2016).

12. F, Landini, and $\mathrm{M}$, Beramendi. Construction and validation of a psychometric scale to assess extension agents' beliefs about extension and innovation. The Journal of Agricultural Education and Extension. DOI: 10.1080/1389224X.2019.1643748. (2019).

13. L.S. Mulijanti, A. Sinaga. Effectiveness of jajar legowo planting technology assistance on the change of attitude and knowledge of farmers in Sumedang Regency, West Java Effectiveness of jajar legowo planting technology assistance on the change of attitude and knowledge of farmers in Sumedang Regency, West Java [Internet]. [cited 22 
Februari 2017]. Available from: http://pse.litbang.pertanian.go.id/ ind/pdffiles/prosiding_2016. (2016).

14. A.Y. Fadwiwati. The Effect of High Yield Varieties toward Efficiency, Income, and Corn Distribution Income in Gorontalo. [dissertation]. Bogor Agriculture Institute. Bogor. (2013).

15. L.A, Sutherland., R.J.F, Burton., A, Adamsone-Fiskovica., C,Hardy., B, Elzen,. L ,Debruyne., S, Flanigan. Inclusivity of on-farm demonstration: gender, age, and geographic location. Journal of Agricultural Education and Extension. DOI: 10.1080/1389224X.2020.1828115. (2020).

16. U.P. Astuti, B. Honorita. Improving cognitive and affective of orange's farmer in Lebong District Bengkulu. IAARD Press. Bogor. (2015).

17. B, Lukuyu., F, Places., S, Franzel,. E, Kipto. Disseminating Improved Practices: Are Volunteer Farmer Trainers Effective? Journal of Agricultural Education and Extension . 18 (5) 525-540. (2012)

18. M. Taylor dan S. Bhasme. Model Farmers, Extension Networks and the Politics of Agricultural Knowledge Transfer. Journal of Rural Studies. Page 1-10. (2018).

19. Kartono dan N. Amin. Effectiveness of Training in Knowledge Enhancement of Pest and Diseases of Rice Farming. Proceeding. IAARD PRESS. Bogor. (2015).

20. Basrowi dan Siskandar. Study Evaluation Based on Performance. Karya Putra Darwati. Bandung. (2012).

21. J.M, Erbaugh., J.D, Meyer., J.D, Donner., I.M, Kidoido,. Assessing the Impact of Farmer Field School Participation on IPM Adoption in Uganda. Journal of International Agricultural and Extension Education . 17 ( 3) . (2010).

22. U, Khumairo., EA, Lantinga,. Suprayogo, D., Schulte, RPO., Groot, JCJ.. Modifying the farmer field school method to support on-farm adaptation of complex rice system. The Journal of Agricultural Education and Extension. DOI:10.1080/1389224X.2019.1604391. (2019).

23. K, Davis., The complex processes of agricultural education and extension. The Journal of Agricultural Education and Extension. 25(30). P: 193-194. DOI: 10.1080/1389224X.2019.1615170 (2019).

24. K.S. Indraningsih. The influence of the elucidation of farmer decision through the adoption of integrated farming technological innovation. Agro Economy Journal. 29 (1): 1 - 24. (2011).

25. E. Purnomo, N. Pangarsa, K. Boga, Andri, dan M. Saeri. The Effectiveness of Counseling Methods in the Acceleration of Rice Technology Transfer in East Java. Jurnal Inovasi dan Teknologi Pembelajaran. 1 (2): 192-204. (2015).

26. G.O. Manurung, R. Mawardi, dan M.M. Andarias. Increased Knowledge of Katam Training Participants Using Lecture Methods and Practices in Lampung Province. Proceeding of National Seminar Agroinovation Spesific Location IAARD Press. Bogor. (2016).

27. J.M, Laforge and C.Z, Levkoe. Seeding agroecology through new farmer training in Canada: knowledge, practice, and relational identities. Jurnal Local Environment. 23 (10) 991-1007. (2018.). 